See discussions, stats, and author profiles for this publication at: https://www.researchgate.net/publication/228442706

\title{
Criteria-Based Assessment and Grading in Architecture Design Studio
}

Article $\cdot$ January 2012

DOI: 10.1007/978-3-642-25908-1_30

\section{CITATIONS}

0

5 authors, including:

Nangkula Utaberta

Universiti Putra Malaysia

303 PUBLICATIONS 679 CITATIONS

$$
\text { SEE PROFILE }
$$

Q

Azami Zaharim

Universiti Kebangsaan Malaysia

337 PUBLICATIONS 2,425 CITATIONS

SEE PROFILE
READS

4,391

(2)

A. I. Che-Ani

Universiti Kebangsaan Malaysia 193 PUBLICATIONS 1,117 CITATIONS

SEE PROFILE

(1) Nurakmal Abdullah Goh

University Malaysia Sarawak 47 Publications 411 Citations

SEE PROFILE

Some of the authors of this publication are also working on these related projects:

Measurement View project

Project Life Cycle Assessment for Solar Photovotaic Technologies View project 


\title{
Criteria-Based Assessment and Grading in Architecture Design Studio
}

\author{
N. UTABERTA ${ }^{1,2}$, B. HASSANPOUR ${ }^{2}$, A.I. CHE-ANI ${ }^{1,2}$, A. ZAHARIM $^{1}$ \\ AND N.A.G. ABDULLAH ${ }^{2}$ \\ ${ }^{1}$ Centre for Engineering Education Research, \\ ${ }^{2}$ Department of Architecture, \\ Faculty of Engineering \& Built Environment, \\ Universiti Kebangsaan Malaysia, \\ 43600 UKM Bangi, Selangor \\ MALAYSIA \\ E-mail: nangkula arch@yahoo.com, badieh.hassanpour@gmail.com, adiirfan@gmail.com, \\ azami.zaharim@gmail.com, akmal.goh@gmail.com \\ Website: $\underline{w w w} \cdot \mathrm{ukm} \cdot \mathrm{my} / \mathrm{p} 3 \mathrm{k}$
}

\begin{abstract}
Education is a contiguous and consecutive process. Thereby learning skills and knowledge in any context, requires strong and potent academic basis. To reach this target, evaluation as a means to recognize student's learning level and making decisions for further educating steps seems essential. All the Educational systems have sort of official examination, assessment or grading policy to measure students taught amount. In the typical policy, students are told clearly about the proposed assessment program and the relative weightings of the various components and they are given timely and helpful feedback after each assessment episode. Internationally, in these decades, universities and educators have become increasingly committed to making assessment and grading more effective in promoting student learning. Appraisal methods and grading systems in studio based educating systems, such as architecture, more than other majors and fields needs attention and scrutiny. Because transmitting the success amount of solving ill-defined problems in design studios to grading symbols are more difficult than multiple choice tests and even open ended questions. The primary interest of this paper is in grading methods that claim to be criteria -based.
\end{abstract}

Key-Words:- Architecture Education, Criteria -based assessment, Grading

\section{Introduction}

Design process in architectural studios is based on some small-small well defined projects during the semester and on final project at the end which is ill defined and in larger scale. Students should finalize their project before deadline and present it in submission day with proper documentation. In this day they have a chance to see other student's project and get the comments from peers and experts and finally they will get mark. Experiences show that students are worry about their grades insofar as they won't attend in discussions if they think their comments will affect grades and with small negative comments or finding fault in their project they get disappointed and loose other statements and suggestions coming after. Most of the student's complain is about the unfairness and inequitable of grades. This may rout in unawareness of the way they evaluate and graded.

On the other hand analysis shows that there is no common understanding of what grading process is in architecture and what occurs in faculties are just instructors experience from what their own professors did. This has inhabited high-quality discourse, research and development of grading system in architecture education. First of all, we have to investigate about the past and current implemented grading systems in architecture faculties to find the characteristics and attributes of idealistic grading systems Since different definitions of some terms related to the discussion are used differently in different countries, and even within a single country, in different education sectors, finding an appropriate terminology to use in analysis of assessment and grading is essential. For instance, 'assessment' in some contexts in the USA refers to the evaluation of a wide range of characteristics and processes relating to higher education institutions, including entry levels, attrition rates, student services, physical learning environments and student achievements. In the UK, assessment can mean what students submit by way of project reports, written papers and the like as distinct from what they produce under examination 